\title{
O. KASPER DRUŻBICKI SJ (1590-1662) I JEGO NAUKA O DOSKONAŁOŚCI CHRZEŚCIJAŃSKIEJ
}

Towarzystwo Jezusowe, założone przez św. Ignacego Loyolę, odegrało ogromną rolę w życiu Kościoła katolickiego na przestrzeni ostatnich sześciu stuleci. Były okresy, w których bez jezuitów niewiele działo się w Kościele. Ze swojego grona jezuici wydali licznych świętych, uczonych, misjonarzy, duszpasterzy, artystów, architektów, poetów, a w ostatnich latach dali światu papieża Franciszka. Do Polski gorliwi zakonnicy dotarli w połowie XVI w. i swoją działalnością postawili tamę, wstrzymującą wielką falę protestantyzmu. Jednym z najwybitniejszych przedstawicieli Towarzystwa Jezusowego był o. Kasper Drużbicki, wychowawca, przełożony, kaznodzieja, pisarz teologiczny, mistyk, twórca polskiej szkoły duchowości religijnej. Na jego temat istnieje pokaźna literatura zarówno w języku polskim, jak i łacińskim, niemieckim oraz francuskim ${ }^{1}$. Celem niniejszego opracowania jest przybliżenie postaci polskiego teologa jezuickiego ze szczególnym uwzględnieniem jego nauki o doskonałości chrześcijańskiej.

\section{Zarys życia i twórczości o. Kaspra Drużbickiego}

Polski jezuita urodził się 6 stycznia I590 r. ${ }^{2}$, jak podał Daniel Pawłowski, jego pierwszy biograf, w święto Epifanii³. Rodzice: Piotr i Elżbieta z Obiezierskich, herbu „Nałęcz związany”, mieszkali we wsi Drużbice, w województwie sieradzkim. Przodkowie Kaspra wybudowali tam kościół i mieli w parafii kapłana (czasem dwóch) ze swojej rodziny. Powstaje wątpliwość, czy ta posiadłość, podczas narodzin Kaspra, należała do jego rodziny. O. Pawłowski, pisząc o jego narodzeniu, podał, że rodzice byli praenobiles in palatynatu Posnaniensi. Kasper Niesiecki w swoim Herbarzu zaznaczył, że posiadłość Drużbice przeszła w ręce Trzebienieckich ${ }^{4}$. Jedynie Fabian Jaroszewicz napisał jasno, że Drużbicki urodził się w województwie sieradzkim5 5 . Być może, jak zaznaczył Jarosław Rejowicz, rodzice Kaspra po sprzedaży rodzinnego majątku przenieśli się w Poznańskie, gdzie zdobyli sobie pewne stanowisko ${ }^{6}$.

\footnotetext{
Zob. J. Majkowski, J. Misiurek, Drużbicki Kasper SJ, w: Encyklopedia katolicka, t. 4, Lublin 1983, szp. $240-241$.

2 Karol Estreicher podał błędnie datę urodzenia: 6 I 1587 r. Por. K. Estreicher, Bibliografia polska, t. 15, Kraków 1897, s. 332.

D. Pawłowski, Vita Patris Gasparis Drużbicki, Polonii Societatis Jesu, Kraków 1670. Tłum. polskie: Wierna życia Wielebnego X. Kaspra Drużbickiego relacja, Zamość 1700, s. 1.

4 K. Niesiecki, Herbarz Polski, t. 3, Lipsk 1832, s. 411.

5 F. Jaroszewicz, Matka świętych Polska, cz. 2, Piekary 1850, s. 4.

6 J. Rejowicz, Kaznodziejstwo Drużbickiego, „Przegląd Powszechny”, 61/1899, s. 209.
} 
Biografowie Drużbickiego podali niezwykłe wydarzenie z jego dzieciństwa. Mianowicie miał on wpaść do wody i zatonąć. Po kilku godzinach został wyciągnięty i cudem ożył. On sam po latach w swoim Libellus illustrationum dziękował Panu Bogu słowami: „Ty mnie bliskiego śmierci, albo już zmarłego, do życia powrócił"'. W domu rodzinnym otrzymał wychowanie w duchu katolickim, gdyż rodzice nie byli zarażeni ówczesnymi nowinkami religijnymi. On sam stwierdził, że temperament miał spokojny, nie stawiał oporu w czynieniu dobra, ani do zła nie był porywczy ${ }^{8}$.

Rodzice oddali syna do kolegium jezuickiego w Poznaniu, gdzie pobierał nauki humanistyczne. Był pilnym i zdolnym uczniem, wyróżniającym się wśród kolegów, pochodzących z różnych stron Rzeczpospolitej Obojga Narodów. Obserwując styl życia synów św. Ignacego Loyoli, podjął decyzję wstąpienia do jezuitów. I sierpnia I609 r. przekroczył próg nowicjatu w Krakowie i pod okiem mistrza o. Andrzeja Gutthaetera Dobrodziejskiego przez dwa lata wspinał się po szczeblach doskonałości zakonnej. W swoim pamiętniku duchownym napisał, że Pan Bóg dał mu skruchę i pogardę dla siebie samego oraz nabożeństwo do Męki Pańskiej, Najświętszego Sakramentu i do Matki Bożej, która uzdrowiła go z choroby płuc, na którą zapadł przed wstąpieniem do nowicjatu. Na kartach pamiętnika zamieścił też modlitwę, będącą wyrazem wdzięczności za łaskę powołania: „Kazałeś mi Panie, abym Ci się oddał ofiarą zupełną i nieustanne całopalenie przez śluby doskonałości na ołtarzu dobrowolnym, ogniem miłości, abyś mnie sam, jako mnie na pierwszym do Zakonu wejściu, z rąk Najświętszej Maryi, Matki i Pani mojej najdroższej wziął sobie za sługę, potem mnie na ołtarzu krzyża twego odebrał sobie za ofiarę Całopalenia. Tak kosztowna była i jest Ci Dusza Moja. Choć ostatnia i najbliższa cząstka stworzenia twego. Więc dziękuje za dar Zakonu, który znam miedzy największymi i skończonymi dobrodziejstwy twymi za najcelniejszy. Za toć błogosławić będę po wszystką Wieczność, wszystkie wnętrzności moje, osobliwym cię wysławianiem, za tę łaskę osobliwą"9.

Po odbyciu nowicjatu Kasper złożył w uroczystość Wniebowzięcia NMP - I5 sierpnia I6II r. pierwsze śluby zakonne. Następnie przeniósł się do Lublina, gdzie przez rok był studentem retoryki, którą wykładał o. Seweryn Branscensis, zamordowany przez innowierców w czasie potopu szwedzkiego ${ }^{\mathrm{I}}$. W latach I6I2-I6I5 studiował filozofię w Kaliszu, słuchając wykładów o. Jana Rogulskiego, którego wykłady zachowały się w rękopisie ${ }^{\mathrm{II}}$ oraz o. Scypiona Kaczorowskiego. W tym czasie rozpoczął lekturę dzieł ascetycznych, rozczytując się w książce $O \dot{z} y$ wocie zakonnym ${ }^{12}$, autorstwa Àlvareza de Paz, wybitnego hiszpańskiego pisarza ascetycznego. Po ukończeniu filozofii, podjął obowiązki nauczyciela poetyki i retoryki w jezuickich konwiktach w Lublinie i Lwowie. W I6I6 r. rozpoczął 5-letnie studia teologiczne w Poznaniu. Spotkał tam znakomitych profesorów: Mikołaja Żorowskiego (moralistę), Baltazara Wolboriusa (biblistę), Jana Borszyńskiego (moralistę), Jakuba Golewskiego (dogmatyka). Zetknął się też z o. Mikołajem Łęczyckim, profesorem

\footnotetext{
Sam Libellus illustrationum zaginął. Po części przedrukował go Daniel Pawłowski w Vita, s. 4.

D. Pawłowski, Wierna życia...relacja, s. 4.

D. Pawłowski, Wierna życia...relacja, s. 4.

10 A. Bober, Sytuacja jezuitów na poludniowo-wschodnich obszarach Rzeczypospolitej w dobie buntu kozackiego (1648-1665), Kraków 1686, s. 31-32.

11 BJ, sygn. 2170, 2902.

12 Książka De vita spiritualis eiusque perfectione została przetłumaczona na język polski pt. $O$ Żywocie zakonnym i wydana w Krakowie w 1613.
} 
egzegezy biblijnej i teologii polemicznej, autorem wielu dzieł ascetycznych i polemicznych, który wywarł znaczny wpływ na jego późniejszą twórczośćc ${ }^{13}$. Pod koniec studiów teologicznych przyjął w I62I r. święcenia kapłańskie w Poznaniu. Jako 3I-letni kapłan dał się poznać jako wytrawny kaznodzieja. Sam wspomniał o nawróceniu jednego Pana, wielkiego nieprzyjaciela Zakonu ${ }^{14}$.

W I622 r. o. Drużbicki przeniósł się do Jarosławia, gdzie pod kierownictwem o. Krzysztofa Angelusa odprawił tzw. III probację, której zadaniem było na wzór dzisiejszego tirocinium pastorale przygotować młodego kapłana-zakonnika do bezpośredniej pracy ewangelizacyjnej. Szalejąca na Rusi zaraza dała mu sposobność do heroicznego aktu miłości bliźniego i złożył ślub usługiwania nieszczęśliwym. Nosił się z zamiarem poniesienia śmierci za Chrystusa, mówiąc: „Najsłodszy Panie Jezu Chryste, któryś męki i śmierć za mnie poniósł, z daru łaski Twojej, pragnę i błagam i ofiaruję się cierpieć i umrzeć za Ciebie. O, obyś mi dał wylać krew i życie za Ciebie położyć, któryś za mnie dał swoje" ${ }^{15}$. Pragnienie męczeństwa było dość częstym zjawiskiem wśród ówczesnych jezuitów. Często wyjeżdżali na misje, a tam niejednokrotnie oddawali życie za głoszenie Ewangelii. Przykładem może być o. Wojciech Męciński, rówieśnik Drużbickiego, który został umęczony za wiarę w Nagasaki w I643 r. ${ }^{16}$

W I623 r. widzimy o. Drużbickiego w Lublinie, gdzie w tamtejszym kolegium pełnił obowiązki wykładowcy logiki. Oprócz zajęć dydaktycznych z młodzieżą przewodniczył sodalicji prawników, bowiem Lublin znany był wówczas z sądów trybunalskich. Zasłynął jako kaznodzieja, pisząc o sobie, iż „sławę moją oddał Bogu na ofiarę" ${ }^{17}$. Okazał się również wytrawnym polemistą, biorąc udział m.in. w dyspucie religijnej o bóstwie Chrystusa z Krzysztofem Lubienieckim Młodszym, ministrem lubelskiego zboru braci polskich. Na jej temat sam adwersarz pisał m.in.: „Najjaśniejszy trybunał, palestra, mnóstwo przyjezdnych panów i szlachty, wojewoda lubelski, Mikołaj Oleśnicki, kasztelan lubelski, Tarło, z wytężoną uwagą przysłuchiwali się tej religijnej szermierce w kościele jezuickim w Lublinie"r8.

Po dwóch latach o. Kasper przeniósł się do Kalisza, gdzie został prefektem studiów. Tam też 3 maja I626 r. złożył śluby wieczyste. 5 sierpnia tegoż roku otrzymał nominację na mistrza nowicjatu u św. Macieja w Krakowie, będąc zarazem rektorem tamtejszego kolegium św. Szczepana. W I629 r. został rektorem wielkiego kolegium św. Piotra i Pawła w Krakowie, będącego fundacją króla Zygmunta III Wazy. W tym samym roku - 6 października - został wybrany prowincjałem prowincji krakowskiej jako następca o. Henryka Picherta. Rządy przekazał mu wizytator Pompilius Lambertengo, wybitny włoski organizator, mając znaczny wpływ na dostosowanie prawa i zwyczajów prowincji polskich do prowincji zachodnich.

Jako przełożony prowincji o. Kasper Drużbicki usiłował łączyć harmonijnie stanowczość z dobrocią. Po przyjęciu urzędu zanosił prośby do Pana Boga: „, ${ }^{\circ}$ ) abym się zawsze Tobie podobał; $2^{\circ}$ ) daj mi mądrość Twoją w rządzeniu; $3^{\circ}$ ) daj mi serce czyste; $4^{\circ}$ ) kieruj moją ręką w pisaniu, językiem w mówieniu, myślą w rozumieniu, daj mi zdrowie, siły mocne do pracy; $5^{\circ}$ ) daj mi uczucie do modlitwy, daj mi Boże wykonywać to wszystko, co rozkażesz,

13 L. Grzebień, Łęczycki Mikołaj (1574-1653), w: Stownik polskich teologów katolickich, t. 2, Warszawa 1982, s. $560-566$.

14 D. Pawłowski, Wierna życia ...relacja, s. 10.

15 J. Rejowicz, Kaznodziejstwo Drużbickiego, s. 211.

16 W. Padacz, Z polskiej gleby, Kraków 1973, s. 446-461.

17 D. Pawłowski, Wierna życia...relacja, s. 11.

18 K. Lubieniecki, Disputatio Lublini cum Gaspare Drużbicki Jezuita habita, Raków 1627. 
a rozkaż, co Ci się podoba" ${ }^{19}$. Jako przełożony prowincji był bardzo ostrożny w przyjmowaniu kandydatów do zakonu i nie chciał, aby powstawało zbyt wiele placówek, troszcząc się o odpowiednie podstawy materialne do ich funkcjonowania. Wielką wagę przywiązywał do rozwoju misji, polecając przygotowywanie młodych misjonarzy w duchu gorliwości i poświęcenia. Troszczył się o pozyskiwanie prawosławnych do katolicyzmu w duchu zasad unii brzeskiej. Zachęcony przez biskupa lwowskiego Jana Andrzeja Próchnickiego, wysłał 28 października I629 r. na synod unicki we Lwowie dwóch współbraci: o. Bambusa i o. Szczytnickiego, aby ,łagodnymi sposobami i prywatną rozmową umysły do zgody i zlania się obydwu wyznań przygotowali”" ${ }^{20}$. Pierwszy z nich na synodzie wygłosił porywające kazanie. Jako prowincjał w I630 r. ułożył i wydał 28 reguł dla prokuratorów i administratorów jezuickich folwarków, które obowiązywały aż do kasaty w I773 r. W podanych przepisach widoczna była aprobata gospodarki folwarczno-pańszczyźnianej, a zarazem bardzo ludzkie podejście do poddanych. Jeszcze bardziej ujawniło się to w memoriale Drużbickiego do przełożonych domów zakonnych z I63I r.: „Niech wiedzą - pisał - wszyscy przełożeni i podwładni, że nikomu z naszych nie wolno uderzyć w twarz lub bić służących i poddanych i to pod surową karą" 2 .

W czasie sprawowania rządów przez o. Drużbickiego doszedł do zenitu spór między Towarzystwem Jezusowym a Akademią Krakowską. Dotyczył on utworzenia w Krakowie własnej wyższej szkoły - akademii, podobnie jak w Wilnie. Duszą tychże zabiegów był o. Mikołaj Łęczycki. Akademia Krakowska wszelkimi sposobami broniła swoich praw i sprawa oparła się o Rzym. Rota rzymska wydała wyrok wykonawczy „executorales”, pozwalający jezuitom na otwarcie własnej szkoły, który został ogłoszony w Krakowie 22 maja I630 r. w kolegium św. Piotra w obecności nuncjusza Antoniego Santacroce, prowincjała Drużbickiego, księży i zakonników. Wydawało się, że jezuici zwyciężyli, lecz było to zwycięstwo połowiczne. Po śmierci bowiem króla Zygmunta III Wazy w I632 r., wielkiego protektora jezuitów, Akademia Krakowska wzmogła walkę z zakonnikami. Walka toczyła się głównie na pióra i stała się okazją do powstania bogatej literatury antyjezuickiej. Profesor Neyman wydał aż sześć broszur, z których najważniejszą była Memoriale eksorbitancji i procesu Akademii Krakowskiej z Jezuitami o szkoły krakowskie. W odpowiedzi jezuici ogłosili pięć pism ulotnych i dwie większe rozprawy. Autorem odpowiedzi na Memoriale Neymana był sam prowincjał o. Drużbicki, który wydał pismo polemiczne pt.: Deklaracja memoriału ekserbitancji i procesu Akademii Krakowskiej między stany koronne poddanego. Na sejmie konwokacyjnym Io października I632 r. sprawę sporu oddano w ręce królewicza Władysława. Pod koniec tego miesiąca odbył się trybunał rozjemczy, w którym ze strony jezuitów wzięli udział: Drużbicki, Rudnicki, Szembek i Brzechwa. Spór nie został rozstrzygnięty i król Władysław IV Waza odniósł się do Stolicy Apostolskiej. Pod koniec I633 r. o. Kasper napisał rozprawę pt.: Powody dla których Ojciec św..., w której spokojnie i rzeczowo przedstawił cały problem. Papież Urban VIII skłonił się ku prośbie władcy polskiego i nakazał zamknięcie publicznych szkół w Krakowie. Jezuici dostosowali się do dekretu papieskiego i od I634 r. utrzymywali w Krakowie jedynie czteroletnie studia teologiczne dla swoich kleryków ${ }^{22}$.

\footnotetext{
19 D. Pawłowski, Wierna życia ...relacja, s. 32.

20 Tamże, s. 41.

21 S. Załęski, Jezuici w Polsce, t. 2, Lwów 1901, s. 718-719.

22 Memoriale exorbitancji i procesu Akademii Krakowskiej. BOssol, sygn 719.
} 
Z końcem I632 r. o. Drużbicki oddał prowincjalstwo swemu następcy o. Marcinowi Hińczy, autorowi książek ascetycznych ${ }^{23}$. Sam objął przełożeństwo kolegium w Kaliszu, będące fundacją prymasa Stanisława Karnkowskiego. Troszczył się o doczesne potrzeby zakonników, szkolnictwo, bibliotekę i drukarnię. W I634 r. przeniósł się do Jarosławia, gdzie przejął obowiązki instruktora III probacji. Starał się, aby młodzi księża zakonni przez rok oddawali się głębszemu poznaniu duchowości jezuickiej i prawa zakonnego oraz odpowiednio przygotowani odprawili wielkie rekolekcje, trwające 30 dni. Utrzymywał kontakty przyjaźni z księżną Anną z Kostków Ostrogską, fundatorką jezuickiej rezydencji jarosławskiej. Dzięki jej funduszom odnowiono kościół, w którym była czczona od I38I r. figura Matki Bożej.

W I636 r. o. Kasper poświęcił się wzmożonej pracy kaznodziejskiej, obejmując ambonę trybunalską w Lublinie. Z wielkim zaangażowaniem przemawiał do członków trybunału koronnego i mieszanego audytorium szlachty, mieszczan i ludu. Pozostawił w rękopisie 24 tomy kazań i egzort (8 t. egzort - do osób zakonnych, 6 t. - kazań niedzielnych, 4 t. kazań świątecznych, 2 t. kazań przygodnych, 3 t. materiałów homiletycznych, I t. egzort domowych). W historii polskiego kaznodziejstwa można go zaliczyć do kaznodziejów przejściowych między okresem klasycyzmu a następującym okresem panegiryzmu. Z jednej bowiem strony posługiwał się językiem czystym, dobrze zachowaną formą kaznodziejską, podawał jasny i gruntowny wykład prawd wiary, a z drugiej strony można dostrzec pewne cechy zepsucia: zbytnią czasem kwiecistość, nagromadzenie synonimów wokół jednego przedmiotu, wywody etymologiczne. W I650 r. odrzucił propozycję króla Jana Kazimierza objęcia funkcji królewskiego kaznodziei. „O śmierci i o sądzie bliskim mnie myśleć - pisał do władcy - a nie po poklasku zbieranym przez kaznodzieję. Wyznaję zasady kaznodziejskie niezgodne z tymi, jakie są mile widziane na dworze, gdzie się gardzi dowodami i uczuciem, a lubuje się w konceptach, subtelności i nowikach" ${ }^{24}$. Niektóre swoje kazania o. Kasper tłumaczył na język łaciński, aby zagraniczni kaznodzieje mogli również korzystać z jego myśli. Ponadto wydał drukiem opracowane wskazania dla zakonnych siewców słowa Bożego, które dotyczyły przygotowania i wygłaszania kazań na ambonach. Uprzytamniał im, iż celem kazania ma być zachęta i nakłonienie słuchacza do głębszej miłości i naśladowania Chrystusa. Dlatego postulował akcentowanie strony moralnej, zastosowań praktycznych i momentów emocjonalnych, czyli wpływ na wolę i uczucie, przy dobrym przedstawieniu treści prawd wiary. Dlatego zalecał kaznodziejom częstą modlitwę o łaskę poznania treści Biblii i o dary jakby prorockie ${ }^{25}$, dokładne poznanie środowiska, napisanie tekstu kazania, dogłębne opanowanie tematu i pamięciowe przyswojenie treści do konkretnych potrzeb słuchaczy ${ }^{26}$.

Na lata I638-I64I przypadają rządy o. Drużbickiego w kolegium ostrogskim, którego fundatorką była świątobliwa Anna Alojza Chodkiewiczowa, żona hetmana Jana Karola

\footnotetext{
23 Zob. L. Grzebień, Hańcza Marin (1592-1668), w: Słownik polskich teologów katolickich, t. 2, Warszawa 1982, S. 50-51.

24 J. Rejowicz, Kaznodziejstwo Drużbickiego, „Przegląd Powszechny”, 62/1899, s. 81.

25 Niektórzy biografowie podali, że o. Drużbicki posiadał dar proroctwa i był uważany przez mieszkańców Poznania za naszego proroka. Przekazali też pewne fakty, świadczące o tym darze: pani Tomickiej przepowiedział, że przy jej śmierci nie będzie żadnego jezuity, choć za życia są jej duchowymi przewodnikami; dokładnie określił dzień śmierci księżny Ostrogskiej, wojewodziny wileńskiej; Tomaszowi Zamoyskiemu, kanclerzowi koronnemu przepowiedział, że żona porodzi mu dwie córki, a następnie syna. D. Pawłowski, Wierna życia...relacja, s. 75; K. Niesiecki, Herbarz Polski, t. 3, s. 417; F. Jaroszewicz, Matka Świętych Polska, cz. 2, s. 8.

26 W. Urban, Praktyczne rady kaznodziejskie ks. Kaspra Drużbickiego, „Wiadomości Duszpasterskie”, 4/1948, nr 1, s. 10-13.
} 
Chodkiewicza. W tym okresie istniał w Ostrogu kurs filozoficzny dla kleryków jezuickich. W I640 r. Chodkiewiczowa ufundowała bursę dla synów ubogiej szlachty wołyńskiej, przeznaczając osobny dom dla 20 uczniów. W I64I r. hojna fundatorka przekazała dom z ogrodem za miastem dla bursy muzyków. O. Kasper jako rektor kolegium troszczył się o bibliotekę, powiększając jej zbiory i w I64I r. rozbudował aptekę, która rozwijała się bez przeszkód.

3 lipca I640 r. odbył się w Ostrogu wspaniały jubileusz zakonny, przygotowany przez regensa, o którym pisał jezuicki historiograf: „Czego tam nie było. Więc łuki tryumfalne, 3 orkiestry: hetmanowej, ordynacka i studencka, ognie sztuczne, salwy. Więc trzydniowa misja ludowa i wspaniałe egzekwie za duszą fundatorów i dobrodziejów zakonu, jak przygotowanie do uroczystości, więc sumy, nieszpory i kazania podczas samej uroczystości, więc actio scholastica dramat polski pt. „Tryumf zakonu w pierwszym swym wieku”, który i hetmanowej i zacnym gościom z Wołynia i Polesia się podobał. Przez 8 dni po Ioo ubogich zasiadało do stołu, który obsługiwali na przemian księża i klerycy Jezuici. Na obicia, drogie dywany, materye, ozdoby kościelne, hetmanowa wydała kilka tysięcy zł. polskich. Do kuchni dać kazała dwa woły, cieląt, drobiu, jarzyn ile potrzeba. Duszą jubileuszowej uroczystości był rektor, świętobliwy Kasper Drużbicki" 27.

W I640 r. na kongregacji prowincji polskiej w Jarosławiu rektor o. Kasper podpisał przyłączenie do kolegium ostrogskiego rezydencje: ksawerowską ${ }^{28}$, perejasławską ${ }^{29}$, nowogrodzką $a^{30}$ i winnicką ${ }^{3 \mathrm{I}}$.

W I64I r. widzimy o. Drużbickiego w Krakowie, gdzie pełnił obowiązki rektora i mistrza nowicjatu przy kościele pw. św. Szczepana. Nowicjat został przeniesiony w czerwcu I586 r. z Braniewa i umieszczony w dawnej plebanii, mając do wyłącznego użytku kaplicę pw. św. Macieja w kościele gotyckim z ok. I300 r. O. Kasper podał pewne zasady, które należy stosować w kierownictwie duchowym. Jego zdaniem kierownik duchowy powinien posiadać upoważnienie od swoich przełożonych do prowadzenia dusz i być zdolnym, i odpowiednio przygotowanym do podjęcia odpowiedzialnych obowiązków. Istotą kierownictwa duchowego jest pomoc w rozpoznaniu powołania, aby zostało ono przyjęte i zrealizowane w życiu. Według niego ważny jest stały kontakt osoby kierowanej z kierownikiem duchowym, który zawsze powinien mieć czas na duchowe rozmowy. Osoba kierowana powinna mieć szacunek i zaufanie wobec przełożonego, od którego z pokorą ma przyjąć odpowiednie wskazówki. O. Kasper polecał też mieć dobrych przyjaciół, którzy z życzliwością zwrócą uwagę i pomogą w dążeniu do doskonałości ${ }^{32}$. Będąc mistrzem nowicjatu, zdawał sobie sprawę, jak ważną

\footnotetext{
27 S. Załęski, Jezuici w Polsce, t. 4, s. 1269.

28 Ustawiczne najazdy Kozaków nie pozwoliły na rozwój Ksawerowa. Po 1664 r. rezydencja przestała funkcjonować, a fundację przeniesiono z Ksawerowa na rezydencję w Owruczu. Por. Encyklopedia wiedzy o jezuitach na ziemiach Polski i Litwy 1564-1995, oprac. L. Grzebień, Kraków 1996, s. 339-340.

29 Rezydencja w Perejasławiu, z fundacji Łukasza Żółkiewskiego, starosty perejasławskiego, została w 1648 r. zdobyta przez Kozaków i zamieniona na klasztor prawosławnych bazylianów. Por. Słownik geograficzny Królestwa Polskiego i innych krajów słowiańskich, t. 7, s. 955-956.

30 Rezydencja jezuicka w Nowogródku istniała w 1. 1631-1714, stając się następnie kolegium, które przetrwało do kasaty. Por. Encyklopedia wiedzy o jezuitach..., s. 464.

31 Rezydencja w Winnicy, z fundacji Walentego Aleksandra Kalinowskiego, w 1648 r. została zajęta przez Kozaków i dopiero rozwijała się od 1732 r. W 1. 1630-1648 funkcjonowały szkoły i bursa dla ubogich scholarów. Czynny był teatr szkolny, a niewielka biblioteka została przewieziona w 1648 r. do Ostroga. Por. S. Załeski, Jezuici w Polsce, t. 4, s. 1081-1092.

32 S. Piotrowski, Zasady duszpasterzowania, „Ateneum Kapłańskie”, 66/1963, s. 145-149.
} 
pełni funkcję i dlatego „każdy nowicjusz w swych trudnościach albo skrupułach, zawsze go miał wolnego i ochotnego" 33 .

W I644 r. o. Drużbicki przeniósł się do ukochanego Poznania i objął obowiązki rektora tamtejszego kolegium. Istniało ono w 1. I57I-I773 i zasłynęło z prowadzonych przez jezuitów szkół, łącznie z Akademią ${ }^{34}$. Jego rządy przypadły na okres wielkich klęsk narodowych w walce z Kozactwem. Widział Rzeczypospolitą w wielkim nieszczęściu i tak mówił na temat przyczyn wojen i klęsk narodowych w kazaniu, wygłoszonym w uroczystość św. Marka Ewangelisty w I649 r.: „Nie zatrzemyjemy się nad obcem głupstwem, ale rozważajmy nasze własne. Jakiemiż to dotąd Bóg przemawiał do nas słowy dobrodziejstw prywatnych i publicznych. Czyż nie wypełniło się na nas słowo Izajasza: „Sedebit populus meus in pulchritudine pacis, in tabernaculis fiduciae, in requie opulenta". Azaliśmy zrozumieli mowę Bożą, że Bóg opiekował się nami, karmił nas? [...] Inny język, którym Bóg przemawia, jest to mowa ucisków i klęsk [...], czyż Bóg nie przemawiał do nas właśnie w tym czasie owym językiem dość często i jasno? Odebrał nam głowę i króla [Władysław IV, zm. 20 V I648], obciął ręce wojsku i wodzom [Żółte Wody II-I6 V I648; Korsuń 20 V I648]. Następnie pierzchnęliśmy, gdy nas nikt nie ścigał [Piławce 23/24 IX I948] zabrano w niewolę nad 30000 naszych ludzi. Iluż zabitych? Jakie obszary spustoszone? Trzecia część królestwa oderwana? I zdajemy się nie mieć dosyć sił ani ducha [...]. Cóż, pytam gdy w samej Rzeczpospolitej przygotowane ludy, żeby nas rozszarpać i rozedrzeć" ${ }^{35}$. Ileż w tym kazaniu uczuć patriotycznych, znaków zapytania, troski o przyszłość Ojczyzny.

W I65I r. o. Kasper rozpoczął restaurację kolegium poznańskiego, mając zamiar przebudować od fundamentów stare zabudowania. Kamień węgielny pod nowy kościół poświęcił biskup Kazimierz książę Czartoryski. Tymczasem wybuchła wojna ze Szwecją i szalejąca po niej zaraza w kraju wstrzymała budowę i doprowadziła kolegium do ruiny. Szwedzi z nienawiści do jezuitów całkowicie spustoszyli najpiękniejsze sale parterowe, zamieniając je na stajnie, a pokoje na piętrze w straszliwy sposób splądrowali.

W okresie poznańskim o. Drużbicki posłował do Rzymu, a w ogóle był w Wiecznym Mieście aż cztery razy. W roku I636 i I643 jako prokurator prowincji polskiej, w I646 r. na VIII kongregacji generalnej i w I652 r. na X kongregacji.

W I652 r. o. Kasper został powtórnie prowincjałem. Rządy nad polską prowincją przekazał mu generał Geswin Nikel. Niewiele zachowało się wiadomości źródłowych o ówczesnym życiu naszego bohatera. M.in. 7 sierpnia I657 r. widzimy go we Lwowie, gdzie w tym dniu witał przed kościołem jezuickim hetmana Stefana Czarneckiego, po jego zwycięstwie nad Rakoczym.

Ostatnim miejscem pobytu i pracy o. Drużbickiego był Poznań, gdzie 29 września I657 r. objął stanowisko rektora tamtejszego kolegium. Było ono zrujnowane - jak wyżej wspomniano - przez potop szwedzki i szalejąca w kraju zarazę. Z zapałem rozpoczął pracę i doprowadził kolegium do dawnego stanu, a nawet posunął budowę kościoła. Wskrzesił zaniedbane nabożeństwa, dźwignął z ruiny gospodarstwa folwarczne, otworzył szkoły. Do końca życia pracował niezmordowanie w konfesjonale i na ambonie. Mając 7I lat życia, głosił kazania pasyjne w Poznaniu.

\footnotetext{
33 D. Pawłowski, Wierna życia ...relacja, s. 42.

34 Zob. L. Piechnik, Działalność jezuitów na polu szkolnictwa w Poznaniu, „Nasza Przeszłość”, 30/1969, s. 171-210 .

35 J. Rejowicz, Kaznodziejstwo Drużbickiego, „Przegląd Powszechny”, 61/1899, s. 417.
} 
Wiosną I662 r. o. Kasper zachorował na febrę i zaopatrzony świętymi sakramentami zmarł 2 kwietnia. Do trumny z ciałem, wystawionej w kaplicy kolegiackiej, cisnęli się mieszkańcy Poznania. Całowali jego szaty, ocierali o nie medaliki, różańce i książeczki, a nawet zaczęli rwać je na kawałki i zabierać jako relikwie. Jezuici byli zmuszeni do przeniesienia go do klasztoru za zakonną klauzurę. Tam przez I7 dni ciało świątobliwego zakonnika spoczywało na katafalku, ponieważ zakonnicy byli zajęci misjami i spowiedziami wielkopostnymi. Na dzień pogrzebu zjechali jezuici i przedstawiciele innych wspólnot zakonnych. Wielotysięczne tłumy ludu żegnały swojego proroka. Pochowano go w krypcie pod kaplicą Matki Bożej w podziemiach wznoszonego kościoła. W I666 r. otworzono zbutwiałą już trumnę i znaleziono niezepsute ciało z wyjątkiem głowy. Świadectwo o tym wydarzeniu wystawili: sufragan poznański Maciej Marian Kurski oraz dwaj komisarze - Stanisław Grundowicz i Jan Regulus. Po zniszczeniu w I698 r. grobowca zakonnego przez wylew Warty, zebrano kości o. Drużbickiego i umieszczono w miedzianej trumnie. W kaplicy Matki Bożej umieszczono wówczas obraz przedstawiający naturalnej wielkości postać o. Kaspra, uważanego już za życia za świętego ${ }^{36}$.

\section{Doskonałość chrześcijańska w ujęciu o. Kaspra Drużbickiego}

O. Kasper Drużbicki napisał kilka dzieł o doskonałości chrześcijańskiej, do których należy zaliczyć: Droga doskonałości chrześcijańskiej (Kalisz I665, I74I, I79I, Lwów I667), Szkoła doskonatości chrześcijańskiej (Poznań I87I), Przemysty zysku duchowego albo nauki do prędkiego w drodze Bożej postępku (Kraków I67I, I672, Gdańsk I672, Kalisz 1685, Wilno 1708, Lwów I746, Poznań I750, I866), Sublimitas perfectionis religiosae (Praga 1713, Ingolstadt 1732) i Tractatus de brevissima ad perfectionem via hoc est de perenni divinae voluntatis intentione, executione, apprehensione (Kalisz I682) ${ }^{37}$. To ostatnie dzieło służy za podstawę do niniejszego opracowania.

Na czym przeto polega według naszego mistrza życia duchownego doskonałość chrześcijańska? Odpowiedź jest prosta: „,doskonałość chrześcijańska - pisał - i prawdziwa świętość istnieje w zjednoczeniu z Bogiem", czyli doskonałość jest tym samym, co świętość. Autor tymi pojęciami posługiwał się zamiennie. Człowiek o tyle jest doskonałym, o ile uczestniczy w doskonałości Bożej i z Bogiem się jednoczy ${ }^{38}$.

Każdy człowiek - zdaniem o. Kaspra - został powołany do zdobycia doskonałości w zjednoczeniu z Bogiem. W tym celu musi poznać drogi prowadzące do owego zjednoczenia. I tu autor wyróżnia trzy rodzaje ludzi: pierwsi - to ci, którzy uważają, że mają dobry cel, który stawiają sobie nawet przed oczyma, ale wybrali złą drogę i nigdy tego celu nie osiągną; drugą grupę stanowią ludzie, którzy wybrali niezłą drogę, ale długą, z różnymi wykrętami, przeszkodami i tacy wcześniej umierają, niż doskonałość osiągają; do trzeciej grupy należą tacy, którzy wybierają krótką i bezpieczną drogę, i najszybciej dochodzą do zjednoczenia

36 J. Mandziuk, Życie i twórczość ojca Kaspra Drużbickiego, Lublin 1966, mps, s. 41.

37 O. Drużbicki był autorem ok. 40 traktatów teologicznych, kazań, rozmyślań i poradników duchownych, które ujrzały światło druku przede wszystkim po jego śmierci. Były one wielekroć drukowane w różnych miejscach i znalazły się też w wydaniach zbiorowych (Kalisz, t. 1, 1686, Poznań, t. 2, 1691, Ingolstadt, t. 1-2, 1732). Wiele pism pozostało w rękopisach, a niektóre były tłumaczone na język francuski, angielski, hiszpański i niemiecki. Zob. L. Grzebień, Drużbicki Kasper h. Natęcz (1590-1662), w: Stownik polskich teologów katolickich, t. 1, Warszawa 1981, s. 425-428.

38 K. Drużbicki, Tractatus de brevissima ad perfectionem via..., s. 1. 
z Bogiem. Niestety takich ludzi jest najmniej. Człowiek musi więc bardzo uważać, aby nie obrać złej i długiej drogi w dążeniu do świętościi3.

Autor stawia następne pytanie: dlaczego liczni ludzie, aczkolwiek powołani do świętości, nigdy jej nie osiągają. W tym wypadku chodzi mu przede wszystkim o członków wspólnot zakonnych. Sam odpowiada na postawione pytanie, że ci ludzie „równocześnie z Bogiem szukają coś nie dla Boga, a nawet co gorsze, porzuciwszy Boga, szukają czegoś innego" ${ }^{4}$. Często zapatrzeni są w swoje osobiste problemy. Dla takich zjednoczenie z Bogiem jest niemożliwe. „Gdyby ludzie - argumentuje - wiedzieli, mogli, chcieli szukać samego Boga i w Nim samym byli zadowoleni i w Nim wypełnili krąg swoich tęsknot i nie kochali siebie, ani czegoś innego różnego od Boga, wówczas znajdowaliby Go bez żadnego zmęczenia i trudu we wszystkich rzeczach i byliby z Nim zjednoczeni”" 4 .

W drodze do doskonałości człowiek musi jasno postawić sobie cel, którym jest tylko Bóg - „solus Deus et nihil praeter ipsum ”². Poszukiwanie innych rzeczy poza Bogiem jest niegodne dla człowieka. Tymczasem w Kościele jest wiele osób, które wprawdzie pragną dążyć do doskonałości, ale poszukują różnych rzeczy, które ich od Boga oddalają. Ci ludzie szybciej umierają, niż zdobywają doskonałość. Po prostu obrali długą drogę, która nie prowadzi ich szybko do celu.

Dla przybliżenia swoich wywodów jezuicki asceta przytacza cytat z Pieśni nad Pieśniami (6, 8-9): „Sześćdziesiąt jest królowych i nałożnic osiemdziesiąt, a dziewcząt bez liczby, [lecz] jedyna jest moja gołąbka, moja nieskalana, jedyna swej matki, wybrana swej rodzicielki." Według o. Kaspra żonami królewskimi i nałożnicami są ci wszyscy w Kościele, którzy wprawdzie szczerze, ale tylko pośrednio i niedoskonale poszukują Boga. Takich członków Kościoła jest bardzo dużo. Rzadsi są, którzy najdoskonalej i najsłuszniej dążą do Boga, i dlatego są nazwani najdelikatniejszymi gołąbkami.

Autor cy towanego traktatu konkluduje: życie ludzkie na ziemi jest krótkie, stąd człowiek musi dążyć najkrótszą droga do doskonałości. Nie może sobie pozwolić na wykręty i zwłoki. Jeżeli wybierze drogę złą, długą - rzecz prosta - nie dojdzie do doskonałości ${ }^{43}$.

Czy istnieje taka bezpośrednia i najkrótsza droga do doskonałości? Na to pytanie o. Kasper stara się odpowiedzieć w rozdz. IV swojego pisma. Odpowiedź jest twierdząca: taka droga istnieje, a jest nią ta, która „ad Deum per ipsum Deum ducit” "44. Tą drogą jest spełnianie woli Bożej: „Dico: ad Deum perveniendi commodissimam rationem, Voluntatem Dei esse” ${ }^{45}$. Człowiek dążący do doskonałości musi przeto wstąpić na tę jedyną drogę - spełnienia woli Bożej - aby jak najszybciej zjednoczyć się z Bogiem. Najpewniejszym przewodnikiem na tej drodze jest Jezus Chrystus, który sam dał przykład, jak należy wypełniać wolę Ojca Niebieskiego. On ją wypełnił najdoskonalej i ona była pokarmem w jego życiu: „Sola

\footnotetext{
39 Por. W. Urban, Droga do doskonałości chrześcijańskiej wedle księdza Kaspra Drużbickiego, „Wiadomości Duszpasterskie", 4/1948, nr 7/8, s. 267-269.

40 K. Drużbicki, Tractatus de brevissima ad perfectionem via..., s. 5.

41 Tamże, s. 6.

42 Tamże, s. 13.

43 J. Mandziuk, Życie i twórczość ks. Kaspra Drużbickiego i jego nauka o doskonałości chrześcijańskiej, Wrocław 1965, s. 55.

44 K. Drużbicki, Tractatus de brevissima ad perfectionem via..., s. 20.

45 Tamże, s. 21.
} 
Voluntatis Divinae via Christum ad Deum et perducere potuit et perduxit" ${ }^{46}$. Stąd należy Jezusa Chrystusa ściśle naśladować i dążyć do celu bez żadnych zboczeń z wybranej drogi, unikać złych czynności, zmierzających do zakazanych celów, przeciwnych woli Bożej, a wypełniać czynności dobre, zgodne z nią. Czynności bowiem wykonywane przez człowieka są podwójnego rodzaju: dobre, gdy dążą do godziwego celu zgodnego z wolą Bożą oraz złe, gdy zdążają do celu niegodziwego i przeciwnego woli Bożej. Wszystkie przeto czynności ludzkie, prowadzące człowieka do Boga, nie powinny odchylać się od woli Bożej47.

W dążeniu człowieka do doskonałości nie należy - zdaniem o. Drużbickiego - odrzucać środków ludzkich, jak ćwiczenie się w cnotach, w praktykach wzmacniających pobożność, ale one nie mogą zastąpić nastawienia na wolę Bożą. Należy się do nich odnosić z rezerwą, bo kryją w sobie pewne zboczenia z obranej drogi. Autor z całą mocą podkreśla, że tylko „Voluntas Divinae Intentio [...] est Intentio Intentionum, regula regularum, principaliter regula, aliae autem tantum ratione istius" 48 .

Na czym więc polega wypełnienie woli Bożej? Otóż Pan Bóg jedne czynności nakazał człowiekowi do wykonania, a innych zakazał. Przez czynności nakazane o. Kasper rozumie przykazania Boskie, których „necessaria est [...] observantio” "49, oraz postanowienia przełożonych, którzy mają prawo rozkazywać. Człowiek wiernie spełni wolę Bożą przez wykonywanie czynności poleconych bezpośrednio przez Boga, a pośrednio przez ludzi.

Sam o. Drużbicki tak modlił się o zgodę z wolą Bożą: „Na koniec, daj mi Boże mój to wykonywać wszystko, co rozkażesz, a rozkaż coć się podoba, uczyń mię takim, jakim mię chcesz mieć, spraw przeze mnie to, co chcesz, zmiłuj się nade mną zawsze, jako wiesz i chcesz. Zażyj mnie na upokorzenie moje, i na wielkie uwielbienie twoje. Nie dopuszczaj nic czego nie chcesz; nie dopuszczaj na mnie, abym tego chciał czegobyś sam po mnie nie chciał. Niech ci będę zupełnie wiernym, zupełnie statecznym sługą; a Ty Panem moim, abyś we mnie i przez mię były wywyższonym BOŻE moy. Boże najgodniejszy" ${ }^{5}$.

W swoich rozważaniach nad spełnianiem woli Bożej teolog jezuicki podkreślił, że należy mieć odpowiednią intencję. Powinna ona być dobra, roztropna, ochotna, a nade wszystko czysta. Przy wzbudzaniu intencji należy unikać dwóch skrajności: nie wzbudzać tej intencji zbyt często i za ogólnie. Niekiedy można obudzić intencję częściej, zwłaszcza wtedy, gdy mamy coś wykonać zleconego nam przez przełożonego.

Przy spełnianiu czynności zgodnych z wola Bożą mają objawiać się uczucia gorącej miłości, czci synowskiej, częstej bojaźni, ufności pokory, posłuszeństwa, podziwu, że człowiek może tak bardzo zbliżyć się do Pana Boga ${ }^{51}$.

Odnośnie wpływów na ujęcie doskonałości chrześcijańskiej przez o. Drużbickiego należy podkreślić, że pewne myśli zapożyczył on od bł. Henryka Suzo, mistyka średniowiecznego. Jeszcze bardzo uderza pokrewieństwo o. Kaspra ze św. Ignacym Loyolą. Dla obu doskonałość to przede wszystkim szukanie i znajdywanie Boga we wszystkim. A zatem kult i praktyka

\footnotetext{
46 K. Drużbicki, Tractatus de brevissima ad perfectionem via..., s. 25.

47 Tamże, s. 22.

48 Tamże, s. 53.

49 Tamże, s. 55.

50 D. Pawłowski, Wierna życia...relacja, s. 34.

51 J. Mandziuk, Życie i twórczość ks. Kaspra Drużbickiego i jego nauka..., s. 58.
} 
obecności Bożej, woli Bożej, upodobania Boga, kierowanie się we wszystkim dobrą intencją $a^{52}$. W duchu Ćwiczeń i Konstytucji ignacjańskiej polski jezuita szukał Boga we wszystkich stworzeniach, a wszystkich stworzeń w Bogu. Uznawał konieczność oderwania się od stworzeń, aby całą miłość skierować ku ich Stwórcy, ale widział praktyczną niemożliwość wyzbycia się ich całkowicie. Dlatego twierdził, ze trzeba posługiwać się stworzeniami jako darami Bożymi, nie miłując ich dla nich samych ani dla własnej satysfakcji, lecz dla Boga. Jest to najbardziej ignacjańskie podejście do świata. Podejście realne, liczące się z wymogami życia czynnego, apostolskiego, dla zbawienia świata ${ }^{53}$.

$* * *$

O. Kasper Drużbicki w swoim życiu w pełni zrealizował dewizę św. Benedykta z Nursji: Ora et labora. Niemal przez całe swoje życie kapłańskie piastował zakonne urzędy. Rozwinął wszechstronną działalność pisarską, duszpasterską, kaznodziejską i administracyjną. Potrafił równocześnie załatwiać różnego rodzaju sprawy, rozmawiać, dawać wskazówki, nie przerywając pisania swoich dzieł ascetycznych. Spotykamy bowiem u niego ,zharmonizowanie bardzo rzadko idących cech i zalet: życia kontemplatywnego z życiem bardzo czynnym, surowości i ostrości, doprowadzonych do ostatnich granic, z wielką dobrocią i wyrozumieniem dla drugich, uczciwości z trzeźwością i praktycznością" ${ }^{54}$. Wypełniając wolę Bożą, wskazywał innym najkrótszą drogę do doskonałości chrześcijańskiej. Był w pełni realizatorem ignacjańskiej zasady: Ad maiorem Dei gloriam.

\section{Father Kasper Druzbicki SJ (1590 - 1662) and his teaching about Christian perfection Summary}

At their beginnings, Jesuits had a huge impact on the Catholic Church in Poland. They introduced the Council of Trent reform and stopped the spread of Protestanism. Amongst them, there were many mystics, great theologians, missionaries, saints and priests. One of them was Father Kasper Druzbicki, theologian, ascetic writer, preacher and administrator. One of his many theological works is a treaty about the shortest way to Christian perfection, which is God's will fulfillment. The book is not just designed for those in consecrated life, but also in secular life who strive toward holiness.

Keywords: Mysticism, holiness, Society of Jesus, school system, ascetism, monastic life, Trent's reform

Nota o Autorze: Ks. prof. dr hab.Józef Mandziuk, emerytowany prof. zW. PWT we Wrocławiu i w UKSW w Warszawie, profesor uczelniany Politechniki Rzeszowskiej - w Zakładzie Nauk Humanistycznych Wydziału Zarządzania. Autor 8-tomowej Historii Kościoła Katolickiego na Śląsku. Promotor 73 prac doktorskich.

\footnotetext{
52 M. Bednarz, Charakterystyczne cechy mistyki o. Kaspra Drużbickiego. Ateneum Kapłańskie 66(1963), s. 122.

53 J. Mandziuk, Ks. Kasper Drużbicki teolog i mistyk, Warszawa 1969, mps, s. 84-85.

54 S. Bednarski, Drużbicki Kasper, w: Polski Słownik Biograficzny, t. 5, Kraków 1939-1946, s. 404.
} 